\title{
Definitions, key themes and aspects of 'ageing in place': a scoping review
}

\author{
Katinka E. Pani-Harreman ${ }^{1,2 \star}$ (D), Gerrie J. J. W. Bours ${ }^{1,2,3}$, Inés Zander ${ }^{2}$, \\ Gertrudis I. J. M. Kempen ${ }^{1}$ and Joop M. A. van Duren ${ }^{2}$ \\ ${ }^{1}$ Department of Health Services Research, Care and Public Health Research Institute (CAPHRI), Faculty of \\ Health, Medicine and Life Sciences, Maastricht University, Maastricht, The Netherlands, ${ }^{2}$ Research Centre \\ for Facility Management, Zuyd University of Applied Science, Heerlen, The Netherlands and ${ }^{3}$ Research \\ Centre for Community Care, Zuyd University of Applied Science, Heerlen, The Netherlands \\ ${ }^{*}$ Corresponding author. Email: katinka.harreman@zuyd.nl
}

(Accepted 23 December 2019; first published online 18 March 2020)

\begin{abstract}
The purpose is to give an overview of the extent, range and nature of existing definitions of the concept 'ageing in place'. Providing such an overview may be helpful, for policy makers, researchers, communities and service providers, to make sense of the versatility and uses of the concept, and allow the improvement and increase the success of efforts to contribute to the quality of life of older people. The overview was created using Arksey and O'Malley's scoping review methodology. Out of 3,692 retrieved articles, 34 met the inclusion criteria. These studies concentrate on the following five key themes concerning 'ageing in place': 'ageing in place' in relation to place, to social networks, to support, to technology and to personal characteristics. Each of these key themes consists of other aspects, like physical place and attachment to place for the keyword place. This study concludes that the concept 'ageing in place' is broad and can be viewed from different (i.e. five) key themes. A more thorough understanding of 'ageing in place' provides knowledge about the existing key themes and aspects. These findings might provide practical support for professionals and governments when they develop their policies about 'ageing in place' integrally and to develop fit policies.
\end{abstract}

Keywords: 'ageing in place'; independent living; home; liveability; scoping review; older people

\section{Introduction}

Ageing is emerging as a key policy issue. One reason for this is that both the absolute number as well as the proportion of older people in populations around the world are increasing (World Health Organization, 2015). In Europe, the percentage of people aged 65 and over is increasing at an unprecedented rate and is expected to account for over 30 per cent of the population by 2060 (European Commission, 2015). Within the 28 countries of the European Union, approximately nine out of ten people aged 65 and over in Germany, France, Finland and the United

\footnotetext{
() The Author(s), 2020. Published by Cambridge University Press.. This is an Open Access article, distributed under the terms of the Creative Commons Attribution licence (http://creativecommons.org/licenses/by/4.0/), which permits unrestricted re-use, distribution, and reproduction in any medium, provided the original work is properly cited.
} 
Kingdom live independently in their own home. In the Netherlands, the percentage is even higher (95\%). By contrast, Southern and Eastern European countries such as Cyprus, Spain, Portugal and Estonia show particularly low percentages. In these countries, older people more often live in common households together with their children. In Romania, Poland and the Baltic States more than 10 per cent of older people are in this type of living arrangement, which is only practised by 4.6 per cent of senior citizens Europe-wide. It is particularly rare in the Scandinavian countries and the United Kingdom (Eurostat, 2011). These trends affect national policy in all countries and have major implications for the allocation of national resources and budgets (International Federation of Ageing (IFA), 2011). Ageing is also strongly associated with the unpredictability of retirement costs and the costs of care (Van Nimwegen and Ekamper, 2018). Taken together with the fact that a further increase in life expectancy is inevitable, this massive demographic change calls for a major effort to ensure quality of life of the older population (Giacalone et al., 2014). However, the increase in life expectancy may be viewed as a public health achievement, and older people are heterogeneous and many are continuing to help their families and friends even in their later years (IFA, 2011), which is beneficial for older people 'ageing in place'. Additionally, Western countries have been experiencing similar patterns of change in their population due to cultural changes. Not only has life expectancy increased, but also marriage, fertility and birth rates have changed. Most couples have their first child at a higher age than previously, there are more divorces, common-law unions and out of wedlock births. These developments are also called the 'Second Demographic Transition' (Lesthaeghe, 2010) and have led not only to challenges concerning how older people can be supported, in remaining independent and active, but also how the quality of life in general can be improved.

As mentioned earlier, also Western societies are currently dealing with the rapid ageing of their population. Therefore, it is necessary to develop new concepts, programmes and services to fulfil the expectations of their older population, but also for the service providers and policy makers (Iecovich, 2014). Askham, Cameron and Heywood (1999) have studied the wishes and demands of older people concerning their living environment (Means, 2007). They found that older people's choice to stay in their home for as long as possible is especially influenced by policies, but also by their own individual needs. It appears that most older people are attached to their independence and that they prefer to live in the environment with which they are familiar (Machielse, 2016; Vermij, 2016). The main reason for this is that independent living contributes to maintaining a sense of self-reliance, selfmanagement and self-esteem (Milligan, 2009). Machielse (2016) endorses that older people should be able to live independently, provided that their health situation allows them to do so and that there is adequate housing and social support available in their own living environment.

In many countries, the question of whether or not older people continue living in their own house is strongly related to their financial situation, and how it fits with the costs of residential and nursing home provision (Chen et al., 2015). According to Horner and Boldy (2008: 358), "ageing in place' has the potential to provide more appropriate care at a lower cost than a move to a more specialised and sheltered facility'. 'Ageing in place' is mentioned as one possible solution to 
these financial issues. It may save financial expenditures and improve the quality of life of older people (IFA, 2011). The idea behind the policy of 'ageing in place' is that living in a familiar environment has a positive impact on the wellbeing of older people and contributes to positive experiences in later life (Van Dijk, 2015).

Although a field of study about ageing, the needs of older people and the issues brought about by the fact that a large(r) part of society is 65 or over has taken shape over the past the last ten years, the concept 'ageing in place' is used very broadly and has not been defined very clearly so far.

The aim of this study is to identify conventions and patterns in the scholarly treatment of the concept of 'ageing in place'. A more thorough understanding of 'ageing in place' might provide knowledge about the existing key themes and aspects of 'ageing in place' to allow professionals, governments, researchers and communities to attune their policies better. We therefore conducted a scoping review and formulated the following research question:

- How is 'ageing in place' defined in the literature and which key themes and aspects are described?

\section{Methods}

The overview was created using Arksey and O'Malley's scoping review. A scoping review is particularly useful for examining a broadly covered topic to map the literature comprehensively and systematically, and identify key concepts, theories, evidence or research gaps (Arksey and O'Malley, 2005). It also allows the inclusion of many different study designs, which suits the aim of giving an overview of the way researchers define 'ageing in place'. Arksey and O'Malley's scoping review methodology outlines an approach consisting of six stages: (1) identifying the research question, (2) identifying relevant studies, (3) selecting studies, (4) charting the data, (5) collating, summarising and reporting the results, and (6) consultation.

\section{Stage 1: Identifying the research question}

The starting point of this scoping review is the identification of the research question. Arksey and O'Malley (2005) suggest using an iterative process for developing one or more guiding research questions. An exploratory literature study was conducted to increase the authors' familiarity with the literature, so that a research question could be formulated. 'Ageing in place', 'key themes' and 'aspects' were identified as key words for the research question. 'Ageing in place' was operationalised in synonyms (independent living, healthy ageing, housing for elderly and ageing at home) and search terms by the findings of an initial search to become better acquainted with the literature. Key themes was defined as a collection of somewhat related values and aspects. 'Aspects' means the side from which something is considered.

\section{Stage 2: Identifying relevant studies}

The eligibility criteria form the limitations to this research and the base of including or excluding resources. These limitations are strict guidelines and offer a framework 
Table 1. Inclusion and exclusion criteria of studies on definitions, key themes and aspects of 'ageing in place'

\begin{tabular}{|c|c|c|}
\hline & Inclusion criteria & Exclusion criteria \\
\hline Population & $\begin{array}{l}\text { Older people: people who are } \\
\text { currently in the third and fourth age } \\
\text { of life according to the theory of } \\
\text { Peter Laslett (1987). }\end{array}$ & \\
\hline Concept & $\begin{array}{l}\text { Ageing in place. } \\
\text { Ageing at home. }\end{array}$ & $\begin{array}{l}\text { Articles which cover topics clearly } \\
\text { different from goals such as: } \\
\text { - illnesses (e.g. diabetics, HIV, } \\
\text { alcohol abuse); } \\
\text { - long-term care; } \\
\text { - design and architecture/ } \\
\text { construction. }\end{array}$ \\
\hline Context & $\begin{array}{l}\text { All geographic locations. } \\
\text { Older people living independently at } \\
\text { home. }\end{array}$ & $\begin{array}{l}\text { People living in nursing homes, } \\
\text { long-term care facilities or other } \\
\text { institutional care facilities. }\end{array}$ \\
\hline $\begin{array}{l}\text { Types of } \\
\text { sources }\end{array}$ & $\begin{array}{l}\text { Empirical studies, quantitative and } \\
\text { qualitative studies, systematic } \\
\text { reviews, meta-analyses, } \\
\text { meta-syntheses and scoping reviews. } \\
\text { Published in the English, German and } \\
\text { Dutch languages. }\end{array}$ & $\begin{array}{l}\text { Books, narrative reviews, rapid } \\
\text { reviews, critical reviews, PhD theses, } \\
\text { opinion literature, grey literature, } \\
\text { abstracts, conferences and integrative } \\
\text { reviews. }\end{array}$ \\
\hline
\end{tabular}

in order to prevent the research from becoming too broad or even invalid. They also help the researchers (authors KEP-H and IZ) to stay on the same track, while analysing different resources. To set up the inclusion criteria we applied the Population, Concept and Context mnemonic method (Joanna Briggs Institute, 2015). Based on the research objective and research question, we further defined and elaborated the inclusion criteria for the research population, the concept, the context and types of sources. The inclusion criteria used are presented in Table 1.

Five electronic databases (PubMed, PsychInfo, EMBASE, CINAHL and SAGE) were used to find the studies to be analysed for this scoping review. Additionally, three search engines (Google Scholar, and the catalogues of Maastricht University and of Zuyd University of Applied Sciences - both in the Netherlands) were used to optimise the search results of the electronic database searches and to improve the reliability of the search strategy (Bramer et al., 2017). We conducted a search on 3 July 2019, with no restrictions on the date of publication. In addition, reference lists of relevant articles were screened to identify key studies that had been missed.

\section{Research strategy}

The research strategy comprises the choice of resources and the way to find those resources. The authors who reviewed the literature (authors KEP-H and IZ) first agreed on search terms. The selected search terms were combined and tested on the five electronic databases and three search engines. Bramer et al. (2017) argue 
Table 2. Search terms of studies on definitions, key themes and aspects of 'ageing in place'

\begin{tabular}{lll}
\hline Search terms & \multicolumn{1}{c}{ Synonyms } & Linked search terms \\
\hline Ageing in place & - Independent living & - Independent living \\
- Healthy ageing & - Healthy ageing \\
- Housing for the elderly & - Housing for the elderly \\
& - Staying home \\
& - Ageing \\
& - Gerontology \\
& - Wellbeing \\
& - Aged & - Aged \\
& & - Later life \\
& - Third age \\
& - Fourth age \\
& \\
\hline
\end{tabular}

that to reach a maximum recall, searches in systematic reviews ought to include a combination of databases and search terms. Combining the search terms led to a unique search strategy for each of the five electronic databases and each of the three search engines. For example, during our empirical testing, we decided to apply the search term 'ageing at home' to optimise the search results in the search engine Google Scholar. The results of the search terms that we ended up settling on for each database and search engines of the whole search strategy are available on request from the corresponding author. The search terms that the authors settled on and the search strategy are shown in Tables 2 and 3, respectively.

\section{Stage 3: Study selection}

Once the searches (using the indicated search criteria) had been conducted, a selection had to be made from the results, so that actual analysis could take place. This study selection process was conducted on the basis of the inclusion criteria (Table 1), and consisted of three stages, each with a focus on a particular part of the studies (title, abstract and full text). During each of these three stages, the authors divided the studies into relevant, irrelevant and doubtful. Relevant studies are defined here as studies that fit the scope and objective of this scoping review. In order to validate the selection procedure, the inclusion and exclusion criteria were checked for consistency by the two reviewers (authors KEP-H and IZ) independently. This assessment was made first by looking at the title of the articles and then by looking at the abstract of each article. After screening the titles and abstracts, articles that were deemed eligible were obtained as full texts, further scanned for eligibility and finally discussed with the members of the Research Centre of Facility Management, Zuyd University of Applied Science for validation. The Research Centre of Facility Management consisted of experts in health care, facility management and research. For all studies that were excluded on the basis of their full-text articles, the reasons for exclusion were recorded in a logbook. The studies that were left after the third stage of selection were considered relevant for this scoping review. All articles that resulted from conducting the searches in the 
Table 3. Search strategy of studies on definitions, key themes and aspects of 'ageing in place'

\begin{tabular}{|c|c|c|}
\hline & Search strategy & $\mathrm{N}$ \\
\hline \multicolumn{3}{|l|}{ Database: } \\
\hline PubMed & 'Ageing in place' & 87 \\
\hline Psychlnfo & $\begin{array}{l}\text { Concept 'Ageing at home' OR 'Ageing in } \\
\text { place' }\end{array}$ & 82 \\
\hline CINAHL & Ageing in place and seniors & 79 \\
\hline EMBASE & 'Ageing in place' & 75 \\
\hline SAGE & 'Ageing in place' & 56 \\
\hline \multicolumn{3}{|l|}{ Search engines: } \\
\hline $\begin{array}{l}\text { Catalogue of Zuyd University of } \\
\text { Applied Science }\end{array}$ & $\begin{array}{l}\text { Concept 'Ageing at home' OR 'Ageing in } \\
\text { place' 'Communities' }\end{array}$ & 1,424 \\
\hline Catalogue of Maastricht University & $\begin{array}{l}\text { Concept 'Ageing at home' OR 'Ageing in } \\
\text { place' 'Communities' }\end{array}$ & 321 \\
\hline Google Scholar & Concept 'Ageing at home' & 372 \\
\hline \multicolumn{3}{|l|}{ Other resources: } \\
\hline German resources & Konzept 'Zuhause' 'alt werden & 988 \\
\hline Dutch resources & Zelfstandig wonen leven ouderen & 121 \\
\hline Experts & 'Ageing in place' & 60 \\
\hline Key journals & 'Ageing in place' & 27 \\
\hline Total & & 3,692 \\
\hline
\end{tabular}

electronic databases and search engines were exported into Endnote X8, and registered in a logbook, making the part about comparing on the basis of consensus in each stage. If the researchers did not agree on the relevance of a study, a third reviewer (author GJJWB) was asked to decide on the suitability.

\section{Stage 4: Charting the data}

To facilitate the data selection, the researchers agreed to use a chart on which they noted all information that was considered useful. More specifically, they kept track of the following points: author(s), year of publication, country of origin, research aim, research question, study population, sample size, research methodology, definition the authors gave of 'ageing in place', key findings and conclusions.

\section{Stage 5: Summarise and report}

Focusing on definitions, key themes and aspects of 'ageing in place', we conducted a qualitative content analysis (Levac et al., 2010). An open axial coding method was used. The data from the articles were inductively coded in Excel. With open coding, labels were linked to the fragments from Stage 4 (charting the data). These labels summarised the core of the fragment. The labels were then analysed and the 
axial coding method was used to add overarching labels or themes. The analysis resulted in an overview of study characteristics, and an overview of main findings and definitions of 'ageing in place'. Again, two reviewers (authors KEP-H and IZ) independently summarised and reported all results in tables. The content of the tables was then compared and adapted to consensus if necessary.

\section{Stage 6: Consultation}

The consultation stage consisted of two meetings with a focus group. In the first meeting, the validity of the research strategy was discussed. During the second meeting, the results of the research were presented and discussed. The focus group consisted of professionals (a housing corporation representative, a general practitioner, a community nurse, policy staff of health-care and welfare organisations, a local government employee), an older person and a member of a neighbourhood association. All of them, except the older person, assist older people while they 'age in place'. The older person who is part of the focus group was asked to join to represent older people in this scoping review. This consultation phase provided opportunities for stakeholder involvement and provided insights beyond those in the literature.

\section{Results}

\section{Study characteristics}

Five electronic databases and three search engines were searched on 3 July 2019 with no restriction on the date of publication. Based on the first search, 3,692 articles concerning 'ageing in place' were identified. Next, 505 duplicate articles were removed. The titles of the remaining 3,187 articles were then reviewed, on the basis of which 339 articles were deemed suitable for the current study. Independent screenings were then conducted looking at the abstracts of these 339 articles, after which 59 articles were still considered relevant. A final assessment of these articles, this time taking the full text of each of them into account, left a final number of 34 relevant studies for the scoping review. An overview of the data selection process is shown in Figure 1.

The reviewed articles focus on different geographical locations. Most of the studies concern European countries $(\mathrm{N}=17)$, with the Netherlands $(\mathrm{N}=8)$ and Spain $(\mathrm{N}=3)$ being addressed most often, while seven studies each focus on Oceania $(\mathrm{N}=7)$ and North America (i.e. the United States of America $(\mathrm{N}=6)$ and Canada $(\mathrm{N}=1))$. Several different methodologies are used in the 34 selected studies, with the most common being qualitative research methodologies $(\mathrm{N}=21)$, quantitative research methodologies $(\mathrm{N}=8)$ and mixed methods $(\mathrm{N}=5)$. The characteristics and research aims of the articles included in the current scoping review about 'ageing in place' are provided in Table 4.

\section{Definitions of 'ageing in place'}

Turning to the actual content of the selected studies, only two studies developed an explicit definition of 'ageing in place' as a result of empirical research. Most studies cited definitions from other sources, mostly in the introduction of their work. 


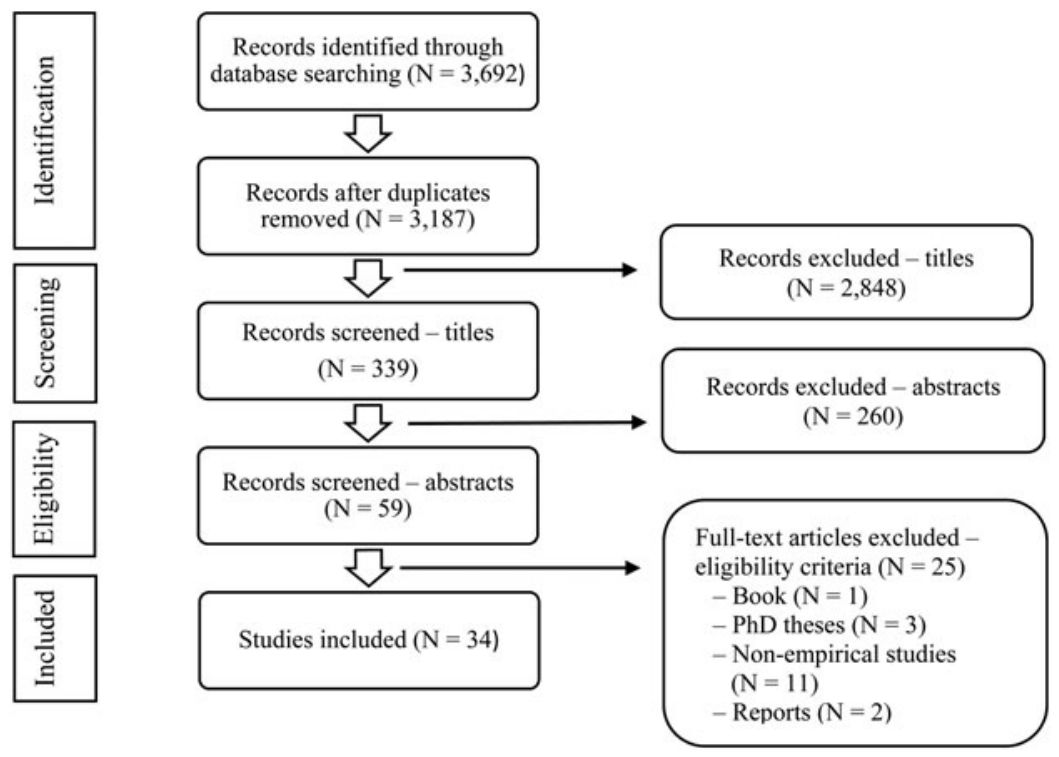

Figure 1. Flowchart of the data selection process of the scoping review on 'ageing in place'.

Although all these 34 included studies examined aspects related to 'ageing in place', none of them were directly focused on the development of a definition of this concept. Only two studies mentioned their own definition of 'ageing in place'. Grimmer et al. (2015) stated that 'ageing in place' is mostly about the opportunity for older people to remain in their own home for as long as possible, without having to move to a long-term care facility. Horner and Boldy (2008: 356) defined 'ageing in place' as a 'positive approach to meeting the needs of the older person, supporting them to live independently, or with some assistance, for as long as possible'.

\section{Key themes and aspects of 'ageing in place'}

By structuring the data, the following key themes of 'ageing in place' were identified: place $(\mathrm{N}=23)$, social networks $(\mathrm{N}=2)$, support $(\mathrm{N}=3)$, technology $(\mathrm{N}=5)$ and personal characteristics of older people $(\mathrm{N}=1)$. See Table 5 for the main findings of the included research papers.

\section{Place}

Twenty-three out of the 34 studies focused on the key theme place. During the analysis of these 23 studies, a distinction between physical place and attachment to place was recognised. Some studies mentioned physical place, while others mentioned attachment to place.

Three levels of physical place are described, namely home, home environment and the neighbourhood. Studies that were focused on the physical home concern the choice between moving and making building modifications to make it easier for older people to continue living in their home (Boldy et al., 2011). Costa-Font 
Table 4. Descriptions of included research papers of scoping review on 'ageing in place'

\begin{tabular}{|c|c|c|c|c|}
\hline Authors (year), country & Study population & Perspective & Research method & Research aim/question \\
\hline $\begin{array}{l}\text { Bradby et al. (2010), } \\
\text { USA }\end{array}$ & $\begin{array}{l}\mathrm{N}=10 \\
\text { (age 90-96) }\end{array}$ & Older people & $\begin{array}{l}\text { Mixed method (in-depth } \\
\text { interviews and participant } \\
\text { observation) }\end{array}$ & $\begin{array}{l}\text { To explore how older women take } \\
\text { responsibility for their own health and } \\
\text { care through adapting everyday } \\
\text { technologies - from slow cookers to } \\
\text { gardening tools to televisions - to fit } \\
\text { their needs and to age comfortably. }\end{array}$ \\
\hline $\begin{array}{l}\text { Magnusson et al. } \\
\text { (2004), Sweden }\end{array}$ & $\begin{array}{l}\mathrm{N}=1,527 \\
\text { (articles) }\end{array}$ & Research & $\begin{array}{l}\text { Qualitative research (systematic } \\
\text { literature review) }\end{array}$ & $\begin{array}{l}\text { To provide an overview of the current } \\
\text { 'state of the art' with regard to } \\
\text { information and communication } \\
\text { technology as a support for frail older } \\
\text { people living at home and their family } \\
\text { carers. }\end{array}$ \\
\hline $\begin{array}{l}\text { Peek et al. (2017), The } \\
\text { Netherlands }\end{array}$ & $\begin{array}{l}\mathrm{N}=33 \\
\text { (seniors) }\end{array}$ & Older people & $\begin{array}{l}\text { Qualitative research (explorative } \\
\text { longitudinal qualitative field } \\
\text { study with semi-structured } \\
\text { interviews) }\end{array}$ & $\begin{array}{l}\text { To understand better the origins and } \\
\text { consequences of technology } \\
\text { acquirement by independent-living } \\
\text { seniors. }\end{array}$ \\
\hline $\begin{array}{l}\text { Peek et al. (2014), The } \\
\text { Netherlands }\end{array}$ & $N=16$ out of 2,841 (articles) & Research & $\begin{array}{l}\text { Qualitative research (systematic } \\
\text { literature review) }\end{array}$ & $\begin{array}{l}\text { To provide an overview of factors } \\
\text { influencing the acceptance of electronic } \\
\text { technologies that support 'ageing in } \\
\text { place' by community-dwelling older } \\
\text { adults. }\end{array}$ \\
\hline $\begin{array}{l}\text { Van Hoof et al. (2011), } \\
\text { The Netherlands }\end{array}$ & $\begin{array}{l}\mathrm{N}=18 \\
\text { (older adults) }\end{array}$ & Older people & $\begin{array}{l}\text { Qualitative research (comprised } \\
\text { of interviews and observations } \\
\text { of technology and } \\
\text { environmental interventions in } \\
\text { the home environment) }\end{array}$ & $\begin{array}{l}\text { To investigate the needs and motives, } \\
\text { related to 'ageing in place', of the } \\
\text { respondents receiving ambient } \\
\text { intelligence technologies, and to } \\
\text { investigate whether, and how, these } \\
\text { technologies contributed to aspects of } \\
\text { 'ageing in place'. }\end{array}$ \\
\hline
\end{tabular}




\begin{tabular}{|c|c|c|c|c|}
\hline Ahn et al. (2020), USA & $\begin{array}{l}N=650 \\
\text { (age } \geqslant 60)\end{array}$ & Older people & $\begin{array}{l}\text { Quantitative research (by an } \\
\text { online survey) }\end{array}$ & $\begin{array}{l}\text { To frame the 'ageing in place' concept } \\
\text { within an extended theory of planned } \\
\text { behaviour model incorporating } \\
\text { environmental domains. }\end{array}$ \\
\hline $\begin{array}{l}\text { Boldy et al. (2011), } \\
\text { Australia }\end{array}$ & $\begin{array}{l}N=6,859, \text { survey } \\
N=39, \text { interviews } \\
\text { (age } 55-75 \text { ) }\end{array}$ & Older people & $\begin{array}{l}\text { Mixed method (survey followed } \\
\text { by structured interviews with a } \\
\text { sub-sample of respondents) }\end{array}$ & $\begin{array}{l}\text { To investigate 'ageing in place' in terms } \\
\text { of house, locality and support, related } \\
\text { to the Western Australia members of } \\
\text { National Seniors Australia. }\end{array}$ \\
\hline $\begin{array}{l}\text { Butcher and Breheny } \\
\text { (2016), New Zealand }\end{array}$ & $\begin{array}{l}\mathrm{N}=8 \\
\text { (older Māori) }\end{array}$ & $\begin{array}{l}\text { Older } \\
\text { peoplePolicy } \\
\text { makers }\end{array}$ & $\begin{array}{l}\text { Qualitative research (qualitative } \\
\text { interviews) }\end{array}$ & $\begin{array}{l}\text { To examine the ways that place } \\
\text { influences experiences of ageing for } \\
\text { older Māori in New Zealand. }\end{array}$ \\
\hline $\begin{array}{l}\text { Costa-Font et al. (2009), } \\
\text { Spain }\end{array}$ & $\begin{array}{l}N=729 \\
\text { (age } \geqslant 55)\end{array}$ & & Quantitative research (survey) & $\begin{array}{l}\text { To examine, in vigorous, moderately } \\
\text { vigorous and less vigorous elderly } \\
\text { people ex-ante and current preferences } \\
\text { for housing (in older age) and its } \\
\text { suitability, given current or future needs } \\
\text { and characteristics. }\end{array}$ \\
\hline $\begin{array}{l}\text { Fernández-Carro } \\
\text { (2016), Spain }\end{array}$ & $\begin{array}{l}N=2,535 \\
\text { (age } \geqslant 65 \text { ) }\end{array}$ & Older people & Quantitative research (data) & $\begin{array}{l}\text { To shed light on the preferred } \\
\text { residential and care arrangements in } \\
\text { later life of the older Spanish } \\
\text { population exploring the willingness for } \\
\text { each one of the alternatives considered: } \\
\text { one's own home, the relative's home } \\
\text { and institutions. }\end{array}$ \\
\hline $\begin{array}{l}\text { Cramm et al. (2018), } \\
\text { The Netherlands }\end{array}$ & $\begin{array}{l}\mathrm{N}=945, \text { questionnaire } \\
\mathrm{N}=32, \text { interviews } \\
\text { (age } 70-93 \text { ) }\end{array}$ & Older people & $\begin{array}{l}\text { Mixed methods (questionnaire } \\
\text { and interviews) }\end{array}$ & $\begin{array}{l}\text { To characterise the relationship } \\
\text { between frailty and ageing in place, and } \\
\text { to identify differences in } \\
\text { neighbourhood characteristics } \\
\text { supporting 'ageing in place' missed by } \\
\text { frail and non-frail older people. }\end{array}$ \\
\hline $\begin{array}{l}\text { Han and Kim (2017), } \\
\text { Australia }\end{array}$ & $\begin{array}{l}N=12,252 \\
\text { (age } \geqslant 55)\end{array}$ & $\begin{array}{l}\text { Older people } \\
\text { Policy makers }\end{array}$ & Quantitative research (data) & $\begin{array}{l}\text { To investigate the preferences of older } \\
\text { people for staying or moving from their } \\
\text { current home and neighbourhood. It }\end{array}$ \\
\hline
\end{tabular}


Table 4. (Continued.)

\begin{tabular}{|c|c|c|c|c|}
\hline Authors (year), country & Study population & Perspective & Research method & Research aim/question \\
\hline & & & & $\begin{array}{l}\text { also elucidates the factors associated } \\
\text { with the decision to age in home and } \\
\text { the decision to age in neighbourhood. }\end{array}$ \\
\hline $\begin{array}{l}\text { Hillcoat-Nallétamby } \\
\text { and Ogg (2014), UK }\end{array}$ & $\begin{array}{l}N=4,079 \\
(\text { age } \geqslant 50)\end{array}$ & Older people & Quantitative research (data) & $\begin{array}{l}\text { To examine the likelihood that a desire } \\
\text { to move will be shaped by dislikes } \\
\text { about home and neighbourhood } \\
\text { environments, amongst older Welsh } \\
\text { people. }\end{array}$ \\
\hline $\begin{array}{l}\text { Horner and Boldy } \\
\text { (2008), Australia }\end{array}$ & $\mathrm{N}=$ not reported & Older people & $\begin{array}{l}\text { Qualitative research (action } \\
\text { research study) }\end{array}$ & $\begin{array}{l}\text { To investigate the complexities and } \\
\text { challenges of change in an aged care } \\
\text { community in Western Australia. }\end{array}$ \\
\hline $\begin{array}{l}\text { John and Gunter } \\
\text { (2016), USA }\end{array}$ & $\begin{array}{l}\mathrm{N}=387, \text { survey } \\
\mathrm{N}=237 \text {, participatory } \\
\text { processes } \\
\text { (elderly people) }\end{array}$ & Older people & $\begin{array}{l}\text { Mixed-method study (survey } \\
\text { and participatory processes) }\end{array}$ & $\begin{array}{l}\text { To gain a better understanding of the } \\
\text { urban and rural contexts for } \\
\text { place-based ageing to inform } \\
\text { programmes and policy. }\end{array}$ \\
\hline $\begin{array}{l}\text { Kerbler et al. (2017), } \\
\text { Slovenia }\end{array}$ & $\begin{array}{l}\mathrm{N}=930 \\
(\text { age } \geqslant 50)\end{array}$ & Older people & Quantitative research (survey) & $\begin{array}{l}\text { Analysing how attached the elderly in } \\
\text { Slovenia are to their homes and wider } \\
\text { living environment and how satisfied } \\
\text { they are with living there. }\end{array}$ \\
\hline Martens (2017), Norway & $\begin{array}{l}\mathrm{N}=27 \\
\text { (articles) } \\
\mathrm{N}=89 \text { (municipalities) }\end{array}$ & Government & $\begin{array}{l}\text { Mixed-method study (structured } \\
\text { literature review and } \\
\text { qualitative/quantitative } \\
\text { document study) }\end{array}$ & $\begin{array}{l}\text { Which housing alternatives are } \\
\text { compatible with the 'ageing in place' } \\
\text { concept? Who are responsible for } \\
\text { providing housing in old age? }\end{array}$ \\
\hline $\begin{array}{l}\text { Mesthrige and Cheung } \\
\text { (2019), Hong Kong }\end{array}$ & $\begin{array}{l}\mathrm{N}=224 \\
\text { (seniors) }\end{array}$ & Older people & $\begin{array}{l}\text { Quantitative research } \\
\text { (questionnaire survey) }\end{array}$ & $\begin{array}{l}\text { To investigate whether the introduced } \\
\text { design elements and facilities satisfy } \\
\text { the numerous special needs of the } \\
\text { seniors in line with the concept of } \\
\text { 'ageing in place'. }\end{array}$ \\
\hline
\end{tabular}




\begin{tabular}{|c|c|c|c|c|}
\hline $\begin{array}{l}\text { Norazizan et al. (2006), } \\
\text { Malaysia }\end{array}$ & $\begin{array}{l}N=386 \\
(\text { age } \geqslant 60)\end{array}$ & Older people & Qualitative research (interviews) & $\begin{array}{l}\text { To describe the difficulties faced by } \\
\text { older Malaysians in their present home } \\
\text { environment. }\end{array}$ \\
\hline Peace et al. (2011), UK & $\begin{array}{l}N=54 \\
\text { (age 61-93) }\end{array}$ & Older people & $\begin{array}{l}\text { Qualitative research (focus } \\
\text { groups) }\end{array}$ & $\begin{array}{l}\text { To reflect the diversity of people and } \\
\text { places in three areas. Metropolitan/ } \\
\text { urban (London Borough of Haringey); } \\
\text { small town/urban/suburban (the town } \\
\text { of Bedford) and small town/village/ } \\
\text { semi-rural (the county of } \\
\text { Northamptonshire). }\end{array}$ \\
\hline $\begin{array}{l}\text { Renaut et al. (2015), } \\
\text { France }\end{array}$ & $\begin{array}{l}\mathrm{N}=11 \\
\text { (age } 79-89) \\
\mathrm{N}=17 \\
\text { (carers) }\end{array}$ & $\begin{array}{l}\text { Older people } \\
\text { Carers }\end{array}$ & Qualitative research (interviews) & $\begin{array}{l}\text { To understand how individuals } \\
\text { construct the space both within their } \\
\text { own home and their immediate } \\
\text { surroundings and how this construction } \\
\text { is linked to their own perception of } \\
\text { ageing and growing old. }\end{array}$ \\
\hline $\begin{array}{l}\text { Roy et al. (2018), } \\
\text { Canada }\end{array}$ & $\mathrm{N}=86$ out of 660 articles & Research & $\begin{array}{l}\text { Qualitative research (systematic } \\
\text { literature review) }\end{array}$ & $\begin{array}{l}\text { To identify the sets of factors } \\
\text { influencing the housing } \\
\text { decision-making of older adults. }\end{array}$ \\
\hline $\begin{array}{l}\text { Sixsmith and Sixsmith } \\
\text { (2008), UK }\end{array}$ & $\begin{array}{l}N=40 \\
\text { (age } 80-89 \text { ) }\end{array}$ & Older people & Qualitative research (interviews) & $\begin{array}{l}\text { To illustrate the problems and } \\
\text { challenges that exists in relation to } \\
\text { 'ageing in place' in the UK. }\end{array}$ \\
\hline $\begin{array}{l}\text { Van Dijk (2015), } \\
\text { The Netherlands }\end{array}$ & $\begin{array}{l}\mathrm{N}=32 \\
\text { (Ireland) }\end{array}$ & Older people & $\begin{array}{l}\text { Qualitative research (discussion } \\
\text { groups) }\end{array}$ & $\begin{array}{l}\text { To examine frail and non-frail older } \\
\text { peoples' perceptions of the relative } \\
\text { importance of ideal neighbourhood } \\
\text { characteristics for 'ageing in place'. }\end{array}$ \\
\hline $\begin{array}{l}\text { Van Hees et al. (2017), } \\
\text { The Netherlands }\end{array}$ & $\begin{array}{l}\mathrm{N}=18 \\
\text { (age } 70-85 \text { ) } \\
\mathrm{N}=14 \text { professionals (social } \\
\text { workers, housing } \\
\text { consultants, neighbourhood } \\
\text { managers and community } \\
\text { workers) }\end{array}$ & Professionals & $\begin{array}{l}\text { Qualitative research (photo } \\
\text { voicing) }\end{array}$ & $\begin{array}{l}\text { To advance the investigation of 'ageing } \\
\text { in place' by not only focusing on which } \\
\text { constraints and regulators older adults } \\
\text { recognise in their environment, but by } \\
\text { also exploring how their constructions } \\
\text { of ageing in place connect or interact } \\
\text { with those of local professionals (social }\end{array}$ \\
\hline
\end{tabular}


Table 4. (Continued.)

\begin{tabular}{|c|c|c|c|c|}
\hline Authors (year), country & Study population & Perspective & Research method & Research aim/question \\
\hline & & & & $\begin{array}{l}\text { workers, housing consultants, } \\
\text { neighbourhood managers and } \\
\text { community workers) who translate } \\
\text { 'ageing in place' policies into daily } \\
\text { practices. }\end{array}$ \\
\hline $\begin{array}{l}\text { Van Hees et al. (2018), } \\
\text { The Netherlands }\end{array}$ & $\begin{array}{l}\mathrm{N}=28 \text { older people } \\
\mathrm{N}=48 \text { (policy makers, } \\
\text { directors, partners of older } \\
\text { people) }\end{array}$ & $\begin{array}{l}\text { Older people } \\
\text { Policy makers }\end{array}$ & $\begin{array}{l}\text { Qualitative research (interviews } \\
\text { and focus groups) }\end{array}$ & $\begin{array}{l}\text { To explore what the development of } \\
\text { lifecycle robust neighbourhoods means } \\
\text { in relation to notions of 'ageing in } \\
\text { place' and age-friendly communities. }\end{array}$ \\
\hline $\begin{array}{l}\text { Vasunilashorn et al. } \\
\text { (2012), USA }\end{array}$ & $\begin{array}{l}\text { Articles published from } 1980 \\
\text { to } 2010\end{array}$ & Research & $\begin{array}{l}\text { Qualitative research (systematic } \\
\text { review) }\end{array}$ & $\begin{array}{l}\text { To examine how the literature on } \\
\text { 'ageing in place' has changed over time } \\
\text { in highly visible gerontology journals, } \\
\text { with a focus on analysing trends related } \\
\text { to the amount, location and variety of } \\
\text { research topics. }\end{array}$ \\
\hline $\begin{array}{l}\text { Wiles et al. (2011), } \\
\text { New Zealand }\end{array}$ & $\begin{array}{l}\mathrm{N}=121 \\
\text { (age 56-92) }\end{array}$ & Older people & $\begin{array}{l}\text { Qualitative research (focus } \\
\text { groups and interviews) }\end{array}$ & $\begin{array}{l}\text { To illuminate the concept of 'ageing in } \\
\text { place' in terms of functional, symbolic, } \\
\text { and emotional attachments and } \\
\text { meanings of homes, neighbourhoods } \\
\text { and communities. }\end{array}$ \\
\hline $\begin{array}{l}\text { Dobner et al. (2016), } \\
\text { The Netherlands, USA }\end{array}$ & $\begin{array}{l}\mathrm{N}=40 \\
\text { (older adults) }\end{array}$ & Older people & $\begin{array}{l}\text { Qualitative research (in-depth } \\
\text { interviews and multiple } \\
\text { (within-case) observations) }\end{array}$ & $\begin{array}{l}\text { What are the experiences of formal and } \\
\text { informal social support and } \\
\text { neighbourhood ties of older adults } \\
\text { 'ageing in place' in Amsterdam and } \\
\text { Portland? And how can differences } \\
\text { between Amsterdam and Portland be } \\
\text { understood in relation to differences in } \\
\text { welfare state arrangements? }\end{array}$ \\
\hline
\end{tabular}




\begin{tabular}{|c|c|c|c|c|}
\hline $\begin{array}{l}\text { Wilkinson-Meyers et al. } \\
\text { (2014), New Zealand }\end{array}$ & $\begin{array}{l}N=3,753 \\
\text { (age } \geqslant 75, \text { New Zealanders) } \\
\text { (age } \geqslant 65, \text { Māori) }\end{array}$ & Older people & $\begin{array}{l}\text { Quantitative research } \\
\text { (questionnaire) }\end{array}$ & $\begin{array}{l}\text { To describe the met and unmet need } \\
\text { for personal assistance reported by } \\
\text { New Zealanders living in the } \\
\text { community. }\end{array}$ \\
\hline $\begin{array}{l}\text { Grimmer et al. (2015), } \\
\text { Australia }\end{array}$ & $\begin{array}{l}\mathrm{N}=42 \\
(\text { age } \geqslant 65)\end{array}$ & Older people & $\begin{array}{l}\text { Qualitative research (interviews } \\
\text { and focus groups) }\end{array}$ & $\begin{array}{l}\text { To explore and synthesise the } \\
\text { experience and perspectives of older } \\
\text { people planning for and experiencing } \\
\text { 'ageing in place'. }\end{array}$ \\
\hline Doblas (2018), Spain & $\begin{array}{l}N=68 \\
\text { (age 63-92) }\end{array}$ & Older people & $\begin{array}{l}\text { Qualitative research (discussion } \\
\text { groups and theoretical } \\
\text { framework) }\end{array}$ & $\begin{array}{l}\text { To examine why living arrangements } \\
\text { among the elderly are changing in } \\
\text { Spain. }\end{array}$ \\
\hline $\begin{array}{l}\text { Roberts et al. (2017), } \\
\text { USA }\end{array}$ & $\begin{array}{l}N=23 \\
\text { (age } \geqslant 65 \text { ) } \\
N=20 \\
\text { (age } 8-25 \text { ) }\end{array}$ & Older people & Qualitative research (interviews) & $\begin{array}{l}\text { To highlight Active Aging for L.I.F.E., an } \\
\text { intergenerational pilot health initiative } \\
\text { developed and implemented in the } \\
\text { state of Oklahoma. }\end{array}$ \\
\hline Versey (2018), USA & $\begin{array}{l}N=98 \\
(\text { age } \geqslant 55)\end{array}$ & Older people & $\begin{array}{l}\text { Qualitative research (interviews } \\
\text { and focus groups) }\end{array}$ & $\begin{array}{l}\text { To explore how neighbourhood } \\
\text { changes are viewed by lower-income, } \\
\text { long-term residents 'ageing in place' in } \\
\text { a neighbourhood that has undergone, } \\
\text { and is still undergoing, waves of } \\
\text { gentrification. }\end{array}$ \\
\hline
\end{tabular}

Notes: UK: United Kingdom. USA: United States of America. 
Table 5. Main findings of included studies of scoping review on 'ageing in place'

\begin{tabular}{|c|c|c|c|}
\hline Authors, country & Key themes & Aspects & Key findings \\
\hline Bradby et al. (2010), USA & Technology & $\begin{array}{l}\text { Mobility } \\
\text { Communications Technologies } \\
\text { Biotechnologies }\end{array}$ & $\begin{array}{l}\text { The spectrum of technologies enables the mobility for } \\
\text { elderly. These tools help them stay connected and in } \\
\text { control, to foster intellectual growth and, by } \\
\text { association, the health benefits that scientists now } \\
\text { associate with brain stimulation. Technologies are key } \\
\text { instruments for self-care, tools that can elicit creativity, } \\
\text { connection, expression, health and even exciting new } \\
\text { challenges. }\end{array}$ \\
\hline $\begin{array}{l}\text { Magnusson et al. (2004), } \\
\text { Sweden }\end{array}$ & Technology & Information and communication technology & $\begin{array}{l}\text { The use of a variety of search terms for information } \\
\text { and communication technology, family carers, older } \\
\text { people and home care in the main brought up the } \\
\text { health telematics literature and, to a lesser extent, the } \\
\text { nursing and gerontology literature. The key theme was } \\
\text { telehealth and telecare models in home care for older } \\
\text { people and their family carers. }\end{array}$ \\
\hline $\begin{array}{l}\text { Peek et al. (2017), } \\
\text { The Netherlands }\end{array}$ & Technology & Acquirements & $\begin{array}{l}\text { A new conceptual model which provides an integrative } \\
\text { perspective on why and how technologies are } \\
\text { acquired, and why these may or may not prove to be } \\
\text { appropriate and effective, considering an } \\
\text { independent-living senior's needs. Externally driven } \\
\text { and purely desire-driven acquirements led to a higher } \\
\text { risk of sub-optimal use and low levels of need } \\
\text { satisfaction. }\end{array}$ \\
\hline $\begin{array}{l}\text { Peek et al. (2014), } \\
\text { The Netherlands }\end{array}$ & Technology & $\begin{array}{l}\text { Support 'ageing in place' } \\
\text { Acceptance }\end{array}$ & $\begin{array}{l}\text { Most articles investigated acceptance of technology } \\
\text { that enhances safety or provides social interaction. } \\
\text { Acceptance in the pre-implementation is influenced by } \\
27 \text { factors, divided into six themes: concerns regarding } \\
\text { technology (e.g. high cost, privacy implications and } \\
\text { usability factors), expected benefits of technology (e.g. } \\
\text { increased safety and perceived usefulness), need for } \\
\text { technology (e.g. perceived need and subjective health }\end{array}$ \\
\hline
\end{tabular}


Van Hoof et al. (2011),

The Netherlands

Technology

Ambient intelligence technology

(safety and security)

status), alternatives to technology (e.g. help by family or spouse), social influence (e.g. influence of family, friends and professional care-givers) and

characteristics of older adults (e.g. desire to age in place).

The most prominent reason was to improve the sense of safety and security, in particular, in case of fall incidents, when people were afraid not to be able to use their existing emergency response systems. The ambient intelligence technologies were initially seen as a welcome addition to strategies already adopted by the respondents, including a variety of home modifications and assistive devices. The systems tested increased the sense of safety and security and helped to postpone institutionalisation.

Ahn et al. (2020), USA Place Environmental domains

The results confirmed the significant mediating role of the TPB (Theory of Planned Behaviour) components between the path from personal, built and interpersonal environments to 'ageing in place' intention. Except for one built environmental construct (housing satisfaction), personal and interpersonal environmental constructs were found to indirectly affect 'ageing in place' intention. One of the interpersonal environmental constructs, social

connectedness, was revealed as the strongest factor in this relationship.

Overall, $44 \%$ of respondents had carried out building modifications to make it easier for them to continue living in their home; this proportion steadily increased with age. Remaining 'independent' is a key aim as people age. The study has shown the importance, both for older people and policy makers, of each of three key themes related to place: 'housing', 'locality' and 'support'. These three key themes, and associated 
Table 5. (Continued.)

\begin{tabular}{|c|c|c|c|}
\hline Authors, country & Key themes & Aspects & Key findings \\
\hline & & & $\begin{array}{l}\text { push-pull factors, have different influences on } \\
\text { people's moving or staying decisions at different } \\
\text { lifestages. }\end{array}$ \\
\hline $\begin{array}{l}\text { Butcher and Breheny } \\
\text { (2016), New Zealand }\end{array}$ & Place & $\begin{array}{l}\text { Physical and social environment } \\
\text { Place attachment } \\
\text { Cultural } \\
\text { identity }\end{array}$ & $\begin{array}{l}\text { Through their connection to place, the participants } \\
\text { drew on a comforting and comfortable dependence on } \\
\text { land and family to enable autonomy in later life. } \\
\text { Rather than seeking to maintain independence in } \\
\text { terms of avoiding reliance on others, older Māori } \\
\text { conceptualised older age through autonomy and } \\
\text { freedom to live in accordance with Māori values. }\end{array}$ \\
\hline $\begin{array}{l}\text { Costa-Font et al. (2009), } \\
\text { Spain }\end{array}$ & Place & $\begin{array}{l}\text { Suitability of housing } \\
\text { Mobility } \\
\text { Accessibility }\end{array}$ & $\begin{array}{l}\text { Adequate housing conditions (mobility/accessibility) } \\
\text { are essential for individual quality of life and certain } \\
\text { aspects of individual wellbeing. 'Ageing in place' } \\
\text { seems to be preferred by the vast majority of the } \\
\text { population, although the suitability of housing for old } \\
\text { age is not guaranteed by encouraging the elderly to } \\
\text { stay in their dwellings. 'Ageing in place' may still be the } \\
\text { preferred option because the psycho-social benefits of } \\
\text { remaining in the same, less uncertain, environment } \\
\text { could outweigh the disadvantages. }\end{array}$ \\
\hline $\begin{array}{l}\text { Fernández-Carro (2016), } \\
\text { Spain }\end{array}$ & Place & $\begin{array}{l}\text { Ideal living environment } \\
\text { Own home } \\
\text { Children } \\
\text { Family-oriented values }\end{array}$ & $\begin{array}{l}\text { About } 90 \% \text { of the respondents declared that they } \\
\text { would prefer to live in their own home as long as they } \\
\text { retain good physical and cognitive functioning, even if } \\
\text { during this time they live alone. They prefer ageing in } \\
\text { their own home if such a situation would imply a } \\
\text { sufficient level of autonomy. On the other hand, when } \\
\text { Spanish older people were asked about their } \\
\text { preferences should they suffer from some physical or } \\
\text { cognitive limitation, more than half - } 56 \% \text { - identified } \\
\text { co-residence with a relative, principally the adult } \\
\text { children's home, as the ideal living environment. }\end{array}$ \\
\hline
\end{tabular}


Cramm et al. (2018),

The Netherlands

Place

Neighbourhood characteristics Supporting

'ageing in place'

Age-friendly environment

Results showed that gender, age and especially frailty were related to missed neighbourhood characteristics. People displayed awareness of their increasing frailty and often acknowledged that it increased the need for neighbourhood characteristics enabling them to age in place. Conclusion is that dependence on neighbourhood varies with frailty status. This

relationship is dynamic; with frailty, older people become more dependent on their neighbourhood.

Han and Kim (2017),

Australia
Place

Home

Neighbourhood

Community

Social ties

People aged 55 and over prefer to stay in their current neighbourhood. They were more likely to intend to move from their current house but not to change thei current local community. Older people with a higher income are more likely to intend to move house but want to stay in the same community to maintain thei strong social ties. Also is found that retirement entails the adjustment of housing consumption; the number of bedrooms in one's current dwelling is an important predictor of downsizing.

\begin{tabular}{|c|c|c|}
\hline $\begin{array}{l}\text { Hillcoat-Nallétamby and } \\
\text { Ogg (2014), UK }\end{array}$ & Place & $\begin{array}{l}\text { Home environment } \\
\text { Attachment to place } \\
\text { Design } \\
\text { Location } \\
\text { Maintenance }\end{array}$ \\
\hline
\end{tabular}

Wishing to move is more pronounced for dislikes about the home than the neighbourhood, and along with our descriptive analysis of the actual nature of dislikes, indicates that older people's concerns about the structural design features, location and maintenance aspects of their home environment can lead to serious consideration of residential mobility. This suggests that the design constraints of the home environment can potentially impede a sense of personal competence about being able to age in place, to the extent that feelings of attachment to place are progressively overridden, giving way to thoughts about the desirability of moving.

(Continued) 
Table 5. (Continued.)

\begin{tabular}{|c|c|c|c|}
\hline Authors, country & Key themes & Aspects & Key findings \\
\hline $\begin{array}{l}\text { Horner and Boldy (2008), } \\
\text { Australia }\end{array}$ & Place & $\begin{array}{l}\text { Wellbeing } \\
\text { Empowerment } \\
\text { Social connection }\end{array}$ & $\begin{array}{l}\text { Older people prefer to live in their own home, rather } \\
\text { than in an institution or care centre. The literature } \\
\text { reveals the importance of wellbeing, expressed as } \\
\text { quality of life, empowerment, 'ageing-in-place' and } \\
\text { social connection. }\end{array}$ \\
\hline $\begin{array}{l}\text { John and Gunter (2016), } \\
\text { USA }\end{array}$ & Place & Community Environment & $\begin{array}{l}\text { For the 'engAGE in Community Age-Friendly Model', } \\
\text { the World Health Organization's 'age-friendly' topic } \\
\text { areas were categorised into three separate (but not } \\
\text { isolated) environmental categories: physical (i.e. } \\
\text { outdoor spaces and buildings, transportation, } \\
\text { housing), social (i.e. social participation, respect and } \\
\text { social inclusion, civic participation, employment) and } \\
\text { service (i.e. communications and information, } \\
\text { community support, health services). }\end{array}$ \\
\hline $\begin{array}{l}\text { Kerbler et al. (2017), } \\
\text { Slovenia }\end{array}$ & Place & $\begin{array}{l}\text { Attachment to home } \\
\text { Wider living environment }\end{array}$ & $\begin{array}{l}\text { The respondents reported that they were very satisfied } \\
\text { with their immediate and wider living environment } \\
\text { and that they were very attached to it. }\end{array}$ \\
\hline Martens (2017), Norway & Place & $\begin{array}{l}\text { Home adaptions } \\
\text { Long-term family home } \\
\text { Familiar surroundings } \\
\text { Housing alternatives } \\
\text { Living in the community }\end{array}$ & $\begin{array}{l}\text { There is no agreement on place in 'ageing in place'. } \\
\text { 'Ageing in place' policies entail joint individual and } \\
\text { public responsibility for housing. Different policy } \\
\text { expressions of 'ageing in place' at national and local } \\
\text { government levels are demonstrated. }\end{array}$ \\
\hline $\begin{array}{l}\text { Mesthrige and Cheung } \\
\text { (2019), Hong Kong }\end{array}$ & Place & Micro-, meso- and macro-scales & $\begin{array}{l}\text { Senior tenants were generally satisfied with the } \\
\text { present living environments in the estates. At the } \\
\text { micro-scale, seniors were satisfied with the level of } \\
\text { privacy and sense of autonomy derived from the } \\
\text { present design features in their homes. For the } \\
\text { meso-scale, the study revealed that the seniors were } \\
\text { particularly satisfied with the design elements such as } \\
\text { convenient transportation and accessibility, including } \\
\text { convenient walkways. At the macro-scale, the }\end{array}$ \\
\hline
\end{tabular}


community care service is deemed important for seniors' wellbeing.

\begin{tabular}{|c|c|c|}
\hline $\begin{array}{l}\text { Norazizan et al. (2006), } \\
\text { Malaysia }\end{array}$ & Place & $\begin{array}{l}\text { Difficulties } \\
\text { Present home environment } \\
\text { Ergonomic } \\
\text { Safety }\end{array}$ \\
\hline
\end{tabular}

Safety

Peace et al. (2011), UK

Place

Micro-environment

Macro-environment

Person environment system related to the quality of later life

Renaut et al. (2015),

Place

France
This paper identified environmental problems and associated factors among older Malaysians. It was found that most environmental difficulties reflected both the permanent and variable environmental conditions. However, research findings also show that the majority of the respondents are satisfied with their living area, as although observations showed there are obvious obstacles and hazards present in all these areas.

The concept of 'option recognition' sets out to capture the extent of environmental impact that can affect decision-making in later life, and points up the importance of continuity and change in both macroand micro-environments. It recognises that individual experience of place is layered and that knowledge of personal biography and experience in time and space leads to greater clarification of the complexity of person-environment interaction. In reconsidering theoretical developments to date in environmental gerontology, the authors have demonstrated the importance of ethnographic research across settings and locations that enable comparability within and between place for older people living in both ordinary and supportive environments.

Individual lifecourse histories combined with socio-economic and socio-psychological factors to shape each individual's perception of the home environment and the adaptions that were made to it in the context of growing old. Four behavioural types are identified that categorise the participants according to how they modify and adapt their home environment: (a) act when the time is right, (b) anticipation and 


\begin{tabular}{|c|c|c|c|}
\hline Authors, country & Key themes & Aspects & Key findings \\
\hline & & & $\begin{array}{l}\text { prevention, (c) situational compromise or resignation, } \\
\text { and (d) recourse to the domestic economy and } \\
\text { co-habitation. }\end{array}$ \\
\hline Roy et al. (2018), Canada & Place & $\begin{array}{l}\text { Housing decision } \\
\text { factors }\end{array}$ & $\begin{array}{l}\text { Overall, a total of } 88 \text { factors were identified, of which } \\
71 \text { seem to have an influence on the housing } \\
\text { decision-making of older adults, although the } \\
\text { influence of } 19 \text { of them remains uncertain due to } \\
\text { discrepancies between research methodologies. }\end{array}$ \\
\hline $\begin{array}{l}\text { Sixsmith and Sixsmith } \\
\text { (2008), UK }\end{array}$ & Place & $\begin{array}{l}\text { Home } \\
\text { Negative aspects }\end{array}$ & $\begin{array}{l}\text { Negative aspects of remaining at home are: barriers in } \\
\text { the home, the symbolic home, hiding increasing frailty, } \\
\text { fearfulness, barriers outside the home, loneliness, } \\
\text { challenges to services. }\end{array}$ \\
\hline $\begin{array}{l}\text { Van Dijk (2015), } \\
\text { The Netherlands }\end{array}$ & Place & Neighbourhood characteristics & $\begin{array}{l}\text { Although both frail and non-frail older people strongly } \\
\text { desired a neighbourhood enabling them to age in } \\
\text { place, they have divergent views on such a } \\
\text { neighbourhood. Frail older people's viewpoint: secure } \\
\text { neighbourhood with facilities nearby, a } \\
\text { neighbourhood with adequate housing and a } \\
\text { supportive network, an accessible neighbourhood. } \\
\text { Non-frail older people's viewpoint: a well-kept } \\
\text { neighbourhood with people to whom you can relate, a } \\
\text { calm neighbourhood with good facilities, lively and } \\
\text { engaged neighbourhood. }\end{array}$ \\
\hline $\begin{array}{l}\text { Van Hees et al. (2017), } \\
\text { The Netherlands }\end{array}$ & Place & $\begin{array}{l}\text { Attachment to place } \\
\text { Amenities } \\
\text { Mobility } \\
\text { Meeting places }\end{array}$ & $\begin{array}{l}\text { Professionals primarily consider objective } \\
\text { characteristics of neighbourhoods such as access to } \\
\text { amenities, mobility and meeting places as important } \\
\text { enablers for older adults to remain living } \\
\text { independently. Analysis of older adults' photographs } \\
\text { and stories show that they associate 'ageing in place' } \\
\text { with specific lived experiences and attachments to } \\
\text { specific, intangible and memory-laden public places. }\end{array}$ \\
\hline
\end{tabular}


Van Hees et al. (2018),

The Netherlands

Place

Attachment to place

Lifecycle robust neighbourhoods

\begin{tabular}{|c|c|c|}
\hline $\begin{array}{l}\text { Vasunilashorn et al. } \\
\text { (2012), USA }\end{array}$ & Place & $\begin{array}{l}\text { Services } \\
\text { Environment } \\
\text { Not one-size-fits-all } \\
\text { Technology }\end{array}$ \\
\hline
\end{tabular}

New Zealand

Place

Functional, symbolic, and emotional

attachments and meanings of homes,

neighbourhoods and communities
'Ageing in place' has a different meaning in policy discourses in practice. While developers mainly considered place as something construable, older people emotionally attached to place through lived experiences.

The more specific papers on 'ageing in place' focus on services (e.g. nursing homes and assisted living facilities, health monitoring, housing and social support, and palliative care). Second, with respect to the environment, 'ageing in place' has two prongs: 'ageing in place' in the home and in other structured settings in the community. Third, 'ageing in place' is not a one-size-fits-all concept. There are multiple issues surrounding differences in 'ageing in place' among diverse populations. Fourth, technology has become an increasingly important component to the literature on 'ageing in place'.

'Ageing in place' is linked to a sense of attachment and social connection, security and familiarity and to a sense of identity, linked to independence and autonomy. The overarching message around 'ageing in place' was that older people wanted to have choices about their living arrangements and access to services and amenities.

Some factors, including the decreasing role of the welfare state, a growing redirection of care into the private sector, alongside the personal desire to stay in one's own home, are becoming increasingly relevant for an unprecedented number of older adults in urban settings. Community support and informal networks among neighbours may become even more vital for older adults living far away from family members. The experiences of older adults of 'ageing in place' in Portland and Amsterdam were found to be 


\begin{tabular}{|c|c|c|c|}
\hline Authors, country & Key themes & Aspects & Key findings \\
\hline & & & $\begin{array}{l}\text { surprisingly similar, in spite of the different national, } \\
\text { institutional and local settings. Fewer available } \\
\text { amenities (grocery stores, pharmacies) and few public } \\
\text { transport options present crucial hurdles to 'ageing in } \\
\text { place', especially in the disadvantaged neighbourhood } \\
\text { in Portland. Strengthened and fostered community } \\
\text { support and social cohesion in both Portland } \\
\text { neighbourhoods may mitigate infrastructural lacks. } \\
\text { However, this places increasing demands on older } \\
\text { adults with limited local support networks and/or } \\
\text { declining health. In contrast, older adults in both } \\
\text { neighbourhoods in Amsterdam raised fewer demands } \\
\text { regarding changing or enhancing the available } \\
\text { infrastructure, amenities or services. }\end{array}$ \\
\hline $\begin{array}{l}\text { Wilkinson-Meyers et al. } \\
\text { (2014), New Zealand }\end{array}$ & Support & $\begin{array}{l}\text { Personal assistance } \\
\text { Instrumental support } \\
\text { Formal support } \\
\text { Informal support }\end{array}$ & $\begin{array}{l}\text { Eighty-one per cent of participants required support } \\
\text { with at least one instrumental activity of daily living. } \\
\text { Sixty-six per cent were meeting their needs with the } \\
\text { support they were currently receiving. Unmet need } \\
\text { was most frequently reported for heavy housework } \\
(65 \%) \text { and light housework ( } 53 \%) \text {. While spouses, } \\
\text { family members and friends were the main providers } \\
\text { of support for light housework, meal preparation, } \\
\text { shopping, finances and transportation, paid staff most } \\
\text { frequently provided personal care and heavy } \\
\text { housework assistance. }\end{array}$ \\
\hline $\begin{array}{l}\text { Grimmer et al. (2015), } \\
\text { Australia }\end{array}$ & $\begin{array}{l}\text { Personal } \\
\text { characteristics } \\
\text { of successful } \\
\text { ageing }\end{array}$ & $\begin{array}{l}\text { Health, information, practical assistance, } \\
\text { finance, activity ( } p \text { hysical and mental), company } \\
\text { (family, friends, neighbours, pets), transport and } \\
\text { safety }\end{array}$ & $\begin{array}{l}\text { Identifying personal characteristics (resilience, } \\
\text { adaptability and independence) and key elements of } \\
\text { successful ageing in place, summarised in the acronym } \\
\text { HIPFACTS: health, information, practical assistance, } \\
\text { finance, activity (physical and mental), company } \\
\text { (family, friends, neighbours, pets), transport and } \\
\text { safety. }\end{array}$ \\
\hline
\end{tabular}


Doblas (2018), Spain

Social networks

ving arrangements

Residential independence

Intergenerational households

Live alone

Roberts et al. (2017), USA

Social networks

Active ageing

Community engagement

Participation

$\begin{array}{ll}\text { Versey (2018), USA } \quad \text { Social networks } & \begin{array}{l}\text { Community } \\ \text { Neighbourhood }\end{array}\end{array}$

Residential independence does not lead to

disconnection, but instead, offers a new framework for intergenerational family relations. Although adapting to living alone is difficult, many elderly assume the challenge of doing so because they feel that no other way of life will guarantee them as much freedom, privacy and autonomy.

Demographic indicators reveal that the overall world population of adults older than 65 years will continue to grow moving forward, underlining the need to communicate to people of all ages that the lifestyle choices made at every point across the lifecourse influence health and wellness. Advances in technology and medicine, as well as improved community and housing options, also highlight the need for programmes to increase awareness of these complex and interconnected issues in an ageing society. The Active Aging for L.I.F.E. programme may be promoted through county extension offices, community centres and in public schools to provide education for improved health and wellness outcomes across the generations.

Given separation from family, rent increases, and paying more for goods and services, the question of whether these changes affected desires to live in Harlem was posed to residents. Overwhelmingly, participants emphasised not wanting to leave their homes or the neighbourhood. Participants preferred to live independently in an urban setting rather than move south with family, relying primarily on neighbours and friends to support everyday activities, such as going to doctors' appointments or grocery shopping. 
et al. (2009) argue that adequate housing conditions such as mobility and accessibility are essential for an individual's quality of life and certain aspects of individual wellbeing. Hillcoat-Nallétamby and Ogg (2014) argue that wishing to move is caused more by dislikes about the home than by the neighbourhood. The built environment has to be changed completely or adapted and improved for people to be physically able to age there (Martens, 2017). The built environment is an important aspect among physical abilities. According to Sixsmith and Sixsmith (2008: 227), increasing frailty and 'barriers in and outside the home' are examples of 'physical health state' and 'the current state of the built environment' having a huge impact on people's independence and thereby on their ability to age in place.

'Ageing in place' is also discussed in the sense of an attachment to place, as a place brings with it certain social connections, security, familiarity and a sense of identity (Wiles et al., 2011). Three levels of attachment to place are described, namely home, home environment and the neighbourhood. As stated before, people normally wish to stay at home for as long as possible, they are quite attached to their home environment. Several theoretical approaches were analysed by Butcher and Breheny (2016) in order to find out what 'attachment to place' really means to older people. According to these authors, attachment to place combines social, environmental, functional, emotional and psychological meanings of place, and this attachment tends to increase over time (Butcher and Breheny, 2016). Therefore, 'ageing in place' includes not only staying in one's own home, but also includes remaining in a stable and known environment where people feel that they belong. Responding to a description of attachment to place by Butcher and Breheny (2016), Van Hees et al. (2017) recently used an approach where place is divided into socially related aspects and physical aspects. The social aspects refer to the place where people live with respect to emotions, memories, experiences and people, whereas the physical aspects are more related to the function and physical or hard elements of the place (Van Hees et al. 2017). Even though 'ageing in place' is mostly related to people ageing in their home, the place and environment they have been living in for a long time, there are several recent theories that redefine the term home in this context. In such theories, home does not only relate to places that people know but also to places that people are attached to emotionally and that allow them to live an individual and self-determined life outside an institutionalised environment (Bartlett and Carroll, 2011). This indicates that 'ageing in place' should not only be understood as people ageing in their own, known houses, but also as having the ability to move within their living environment (Han and Kim, 2017). This can either refer to the social environment, such as when people wish to live geographically closer to their social network, or to the built environment, such as when people move to a place where they can live a more self-determined and independent life. Butcher and Breheny (2016) argue that social environment and family are important. Older people with a higher income are more likely to intend to move from their house but want to stay in their current community to maintain their strong social ties (Han and Kim, 2017). Boldy et al. (2011) argue that the place is a holistic concept consisting of three key themes: housing, locality and support. 'Ageing in place' is not a one-size-fits-all concept. There are multiple issues surrounding differences in 'ageing in place' among diverse populations (Vasunilashorn et al., 2012). 
Summarising these findings, two interpretations of place can be derived from the literature. While the key theme place is used to refer to physical and functional aspects in some cases, it is used to describe much less tangible, rather emotional and experience-based aspects in other cases.

\section{Social networks}

Another way in which 'ageing in place' is viewed in the literature relates more to social networks. Only three out of the 34 studies focused especially on social networks. Doblas (2018) focused on social networks in relation to living arrangements, residential independence and intergenerational households. More specifically, residential independence does not lead to disconnection with the social network, but instead, offers a new framework for intergenerational family relations. Although adapting to living alone is difficult, many older people assume the challenge of doing so because they feel that no other way of life will guarantee them as much freedom, privacy and autonomy. However, whatever the circumstances, the social actors (such as having strong emotional ties to their homes and environment) coincide in stating that they have regular family contact, practically daily with the children and/or other family members to whom they are closest. The relationship is face-to-face when relatives live nearby and, if they do not, the relationship takes place by telephone and in the form of occasional visits (Doblas, 2018). In her study concerning 'ageing in place' in Harlem, New York, Versey (2018) argues that there are also aspects to be careful about, when thinking of the consequences of 'ageing in place'. Adjusting neighbourhoods and bringing diversity to communities may lead to separation from families, rent increases, and paying more for goods and services for the existing current residents of the neighbourhood. The participants of the Versey study stated that they were not willing to leave their current homes, even if it meant being separated from their families. They preferred living in their known urban setting and neighbourhood, being a member of the community and taking part in daily activities, relying on their neighbours and friends. The current residents and their wishes, also concerning their community, can be seen as an important aspect (Versey, 2018). A study by Roberts et al. (2017) concerns the importance of active ageing, community engagement and participation. They confirm that active ageing, community engagement, participation and social cohesion are important elements to engage older people to stay in contact with their social network. The next studies focused on social networks in combination with place or other key themes. As mentioned before, older people prefer to live in an environment (and surrounded by people) to whom they feel attached based on memories and experiences. The environment should be familiar, older people feel attached based on memories and experiences, as a familiar environment gives them a feeling of safety and security (Dobner et al., 2016). This familiar environment can also be related to the social environment and to the people in the social network or community of older people. Older people mostly wish to be engaged and needed within their social network (John and Gunter, 2016). They want to be a part of the community and live a self-determined life. Joining the everyday life of the community leads to a maximisation of their self-fulfilment and enables older people to enjoy their lifestyle (Boldy et al., 2011). Joining the everyday life of the community also includes using the people's own individual talents to support the community. 
Engagement in the community is also important for people's mental health. Being a part of a community may help to prevent loneliness (Sixsmith and Sixsmith, 2008). Overall then, although the theme 'social networks' is mentioned far less than the theme 'place' within the literature in the field, social networks are without doubt acknowledged as playing a part when it comes to 'ageing in place'.

\section{Support}

Two studies focused on support as a key success factor for 'ageing in place'. We found that two different kinds of support were brought up in the literature: formal support and informal support. Formal support is provided by professionals and service providers, while informal support is provided by informal networks consisting of anyone from family members, neighbours and friends, to the community in general. Formal support mainly consists of the infrastructure, facilities and services that are available to the older people in question, such as public transportation, grocery stores, pharmacies, meal services and personal care (Dobner et al., 2016). Paid staff most frequently provide personal care and (heavy) housework assistance (Wilkinson-Meyers et al., 2014). Fewer available amenities (grocery stores, pharmacies) and few public transport options present crucial hurdles to 'ageing in place', especially in disadvantaged neighbourhoods. Strengthened and fostered community support and social cohesion may mitigate infrastructural lacks. According to a study by Wilkinson-Meyers et al. (2014), 81 per cent of the participants required support with at least one instrumental activity of daily living. Sixty-six per cent were meeting their needs with the support they were currently receiving. Unmet need was most frequently reported for heavy housework (65\%) and light housework. The providers of informal support are family members, neighbours, friends and the community in general. They are the main providers of informal support, such as light housework, meal preparation, shopping, finances and transportation (Wilkinson-Meyers et al., 2014). According to Dobner et al. (2016), who focused on informal community support and informal networks among neighbours in their study, informal networks (friends, neighbours, community) may become even more vital for older adults who live far away from family members. Dobner et al. (2016) focused on informal community support and informal networks among neighbours.

Summarising these findings, support concerns personal assistance, the living environment, the daily needs and facilities, and is divided into formal support and informal support. Formal support is provided by professionals and service providers, while informal support is provided by informal networks made up of family members, neighbours, the community and friends.

\section{Technology}

Five out of the 34 studies defined 'ageing in place' in terms of technology. These five studies define technology as one or more of the following: support of mobility, information and communication technology (ICT), biotechnology and ambient intelligence. This spectrum of technology may enable older people to be more mobile. Bradby et al. (2010) stated that the spectrum of mobility technology is much broader than walking sticks, walkers, wheelchairs and stair lifts, and can include everything from automobiles to public transport, security systems, special 
shoes, clothing, medication and heaters. Older people incorporate a range of ICTs, including telephones, computers, televisions and radios, into self-care routines and meaningful activities. These tools not only help them stay connected and in control, but also help to foster intellectual growth and, as such, the health benefits that scientists now associate with brain stimulation (Bradby et al., 2010). Biotechnology, such as pharmaceuticals and over-the-counter medications, are generally associated with health and wellbeing. However, paying attention to the meaning older people attach to medical use and non-use can illuminate how these biotechnologies are positioned as an array of techniques older people use to practise self-care (Bradby et al., 2010). The ambient intelligence technologies were seen as a welcome addition to strategies already adopted by older people, including a variety of home modifications and assistive devices (Van Hoof et al., 2011). Older people have various motives to use ambient intelligence technologies to support 'ageing in place'. The most prominent reason was that using these technologies improved the sense of safety and security that they experience, in particular when it comes to fall incidents. The fear of not being able to use existing emergency response systems in case of such incidents was mitigated by several of such ambient technologies and helped postpone institutionalisation (Van Hoof et al., 2011). Peek et al. (2017) investigated the extent to which older people accept technology and which factors influence this acceptance rate. They found 27 factors which they divided into six themes: concerns regarding technology, expected benefits of technology, need for technology (e.g. perceived need and subjective health status), alternatives to technology, social influence (e.g. influence of family, friends and professional caregivers) and characteristics of older adults (e.g. desire to age in place). Peek et al. (2017) also conducted a study about why and how technologies are acquired by older people and found that externally driven and purely desire-driven acquirements led to a higher risk of sub-optimal use and to low levels of need satisfaction.

In summary, it can be said that technology is a theme of significance when it comes to 'ageing in place', and that it covers a wide range of attributes and tools. Using technology may enable older people to live independently at home and may give them a feeling of safety and security.

\section{Personal characteristics}

Only one study focused on 'ageing in place' in relation to personal characteristics of older people. This study presented older people's views about how they and their peers perceive, characterise and address changes in their capacity to live independently and safely in the community. The authors identified personal characteristics (resilience, adaptability and independence) and key elements of successful 'ageing in place', summarised in the acronym HIPFACTS: health, information, practical assistance, finance, activity (physical and mental), company (family, friends, neighbours, pets), transport and safety. Supporting older people's choices to live safely and independently in the community ('ageing in place') can maximise their quality of life. Little is known of the views of older people about the 'ageing in place' process, and how they deal with the fact that they require support to live in the community accommodation of their choice, as well as how they deal with prioritising their choice (Grimmer et al., 2015). This provided a range of insights about, and strategies for, 'ageing in place'. Participants identified relatively simple, low-cost and 
effective supports to enable them to adapt to change, while retaining independence and resilience. The findings highlighted that successful 'ageing in place' requires integrated, responsive and accessible services. Key personal characteristics of successful 'ageing in place' are being resilient, having adaptability, and being independent, physically and mentally active, and healthy (Grimmer et al., 2015).

\section{Consultation}

After consulting the focus group (Stage 6 in the Methods), the experts agreed with the overview of how 'ageing in place' is framed in existing literature. During the focus group meeting, the study characteristics, definitions, key themes and aspects were presented to the members of the focus group, after which a discussion took place about the results. The members of the focus group recognised and indicated the results found. Additionally, they indicated that one important aspect was not brought forward by the current study, namely the idea that 'ageing in place' should be primarily a long-term solution. According to the members of the focus group, definitions of the concept 'ageing in place' should make mention of long-lasting, durable solutions that allow and support older people to continue living at home, instead of temporary ad hoc solutions. The inclusion of durable solutions should be taken into account in the development of sustainable policies by both government(s), as well as health-care and service providers, where the quality of life and the wellbeing of older people are paramount.

\section{Discussion}

The aim of this scoping review was to identify conventions and patterns in the scholarly treatment of 'ageing in place'. The findings of this study, resulting from an analysis of a total of 34 studies, highlight some key themes (place, social networks, support, technology and personal characteristics) that are largely congruent with the concepts and meanings of 'ageing in place' found in prior research. The majority of the studies that were analysed in the current review focused on aspects related to the key theme place. Two interpretations of place can be distinguished within these 23 studies: while some studies concentrate purely on the physical, functional aspects of place, others describe place in a more psychological way. The latter also has implications for the concept of 'ageing in place', because it does not bind people to one specific geographical place anymore but is more flexible and related to social ties. Another key theme of 'ageing in place' is social networks. Although the theme 'social networks' is mentioned far less than the theme 'place' within the literature in the field, social networks are without doubt acknowledged as playing a part when it comes to 'ageing in place'.

The third key theme is support. Two different aspects of this theme were noticed, namely receiving support and offering support. Two studies relate to the support and assistance that older people receive from policy makers, service providers and the social network. Without this support many people would not be able to 'age in place'. The fourth key theme is related to technology. The five studies that address this theme define the term technology as encompassing one or more of the following: support of mobility, ICT, biotechnology and ambient intelligence. 
Technology is a broad concept. Using technology may enable older people to live independently at home. Only one article (out of the 34) looked into personal characteristics of 'ageing in place'. This article brought forward five key personal characteristics of 'ageing in place', namely resilience, adaptability, independence, physical and mental activity, and health.

To gain an insight into the interrelations among the key themes and aspects, we may look at geographical differences, the development of the concept 'ageing in place' over time, and the relation between different socio-economic, cultural backgrounds and different abilities of older people. We noticed some differences between studies from different continents in terms of the key themes that were mentioned. European studies pay most attention to the two key themes technology and place. Research into the key theme place is also being done in Oceania. The other key themes (social networks, support and personal characteristics) are highlighted across European countries, North America and Oceania. Not all regions cover all the five key themes. This brings a potential risk of lacking attention to one or more themes in those regions which might imply a threat for successful 'ageing in place'. Our recommendation is to make sure that research on 'ageing in place' is conducted in such a way that the focus of conducted studies is distributed in a more balanced way, with each of the five key themes (and the coherence between them) being studied in all geographical regions. The evaluation of an experiment in Rotterdam in the Netherlands shows that this recommendation for an integrated approach of all key themes is valid. The experiment, 'Even Buurten', was part of the National Programme for Elderly Care in the Netherlands (2008-2016) and aimed to support the formal and informal networks around older people so that they can continue to live independently at home for as long as possible (Van Dijk, 2015). The focus of this experiment was on social networks, support, selfreliance (personal characteristics) and the physical environment (place). Technology, supporting 'ageing in place' and attachment to place were not included in this integrated approach, although they are found to be related with 'ageing in place'.

In addition to geographical differences in how research themes are addressed, we also noted differences over time. Vasunilashorn et al. (2012) reported that topics related to the environment and services were the most commonly examined between 2000 and 2010, while the number of studies pertaining to technology and health/functioning was on the rise. According to Vasunilashorn et al. (2012), this underscores the increase in diversity of topics that surround the literature on 'ageing in place' in gerontological research. Our study also shows a development over time with regard to the key themes. The studies related to technology were conducted between 2004 and 2017, those on place between 2006 and 2019, those on support between 2014 and 2016, those on personal characteristics in 2015, and those on social networks in 2017 and 2018. The key theme place is dominant in the evolution of the concept and has appeared more frequently as of late. In other words, a shift is noticeable: from 'hard' aspects of 'ageing in place' (place and technology) to 'soft' aspects (social networks and support).

The context of 'ageing in place' is diverse for older people, depending on their different socio-economic and cultural backgrounds and different abilities. Differences in socio-economic status have been operationalised by Grimmer 
et al. (2015) in a so-called HIPFACTS score (health, information, practical assistance, finance, activity (physical and mental), company (family, friends, neighbours, pets), transport and safety; Grimmer et al., 2015). Lower HIPFACTS scores indicate a modest self-reliance. Modest self-reliance is not found to be beneficial for successful 'ageing in place'.

Due to the scope of our study, we cannot do without a discussion about definitions of 'ageing in place' that the literature provides. Only two definitions of 'ageing in place' were found in the studies we analysed. We compared these definitions to the definition of the Centers for Disease Control and Prevention (CDC) and came to the conclusion that all three definitions have been drawn up from another perspective. The CDC (2019) defined 'ageing in place' as 'the ability to live in one's own home and community safely, independently, and comfortably, regardless of age, income, or ability level'. This definition is particularly based on the ability older persons have or not. Horner and Boldy (2008) defined 'ageing in place' more positively as the extent to which the needs of older persons are met, supporting them to live independently, or with some assistance, for as long as possible. The core of this definition is that support has to meet the needs of older people. Grimmer et al. (2015) stated that 'ageing in place' is mostly about the opportunity for older people to remain in their own home for as long as possible, without having to move to a long-term care facility. This somewhat more narrow definition describes the situation as such. The three perspectives emphasise different components that may be complementary to each other.

\section{Strengths and limitations}

Our review has several strengths. First, we used a comprehensive search strategy across multiple databases and search engines with no date restrictions, minimising the risk of having missed scientific studies about 'ageing in place'. Second, to enhance trustworthiness, the process of selecting studies and extracting charting data was done independently, by two reviewers (Levac et al., 2010). However, the search that was conducted for this study may have also been subject to certain limitations. First, in our search we used a combination of keywords, but 'ageing in place' is a broad concept encompassing a varied terminology. It is possible that we have missed studies that used other terms with similar meanings. In an attempt to limit the effect of this issue, we checked reference lists and asked experts for literature. Second, we limited our search to databases of peer-reviewed, scientific articles. Books, grey literature and discussion papers, for instance, are not included. As a result, we may have missed some definitions of 'ageing in place'. However, we were especially interested in the way 'ageing in place' is defined in the scientific literature, and we did not expect to find this within books and grey literature. Another problem we faced was that scientific publications frequently focus on just one key theme of 'ageing in place', such as place, social networks, support, technology or personal characteristics. It is therefore possible that our overview of key themes and aspects is incomplete and also that more authors than we found used their definition of 'ageing in place'. We attempted to minimise this risk by checking the references for other sources providing more detailed descriptions. In future studies, it might be worthwhile to actively approach the authors of the included studies for 
additional information. A final remark is that we did not assess the quality of the selected studies. However, according to Levac et al. (2010), the strength of the scoping review methodology is that it focuses on the state of research activity rather than evaluating the quality of existing literature.

\section{Conclusion and implications}

The research question of this study was: "How is "ageing in place" defined in the literature and which key themes and aspects are described?' 'Ageing in place' as a result based on empirical research is defined just in a very few studies. Grimmer et al. (2015) stated that 'ageing in place' is mostly about the opportunity for older people to remain in their own home for as long as possible, without having to move to a long-term care facility. Horner and Boldy (2008: 358) defined 'ageing in place' as a 'positive approach to meeting the needs of the older person, supporting them to live independently, or with some assistance, for as long as possible'. From our scoping review, we noticed that the concept 'ageing in place' is broad. We were able to identify five key themes: place, social networks, support, technology and personal characteristics. Professionals and governments should consider including all of these key themes in the development of policies concerning 'ageing in place'. Only then can they handle 'ageing in place' in an integrated way and develop policies that suit older people. Only five out of the 34 included studies focused on social networks (three) and support for older people (two). However, it is assumed that particularly social networks and support have a large impact on 'ageing in place'. Further research into the relationship between 'ageing in place' and communities providing informal support is recommended. Future research on 'ageing in place' will face some serious challenges, such as longitudinal effects, changing populations and shifting health-care policies. There is only one way to deal with these challenges: keep focusing on the quality of life as it is perceived by older people who are ageing in place, because that aim will probably survive some generations.

Acknowledgements. The research was supported by Maastricht University and Zuyd University of Applied Science in the form of sponsoring in time and manpower. The views expressed in the paper are those of the authors.

Conflict of interest. The authors declare no conflicts of interest.

\section{References}

Ahn M, Kang J and Kwon HJ (2020) The Concept of Aging in Place as Intention. The Gerontologist 60 , 50-59.

Arksey H and O'Malley L (2005) Scoping studies: towards a methodological framework. International Journal of Social Research Methodology 8, 19-32.

Askham J, Nelson H, Tinker A and Hancock B (1999) To Have and to Hold: The Bond Between Older People and the Homes They Own. York Publishing Services.

Bartlett H and Carroll M (2011) Ageing in place, down under. GLOBAL AGEING Issues \& Action 7, 2534.

Boldy D, Grenade L, Lewin G, Karol E and Burton E (2011) Older people's decisions regarding 'ageing in place': a Western Australian case study. Australasian Journal on Ageing 30, 136-142. 
Bradby H, Joyce K and Loe M (2010) Doing it My Way: Old Women, Technology and Wellbeing. Technogenarians: Studying Health \& Illness Through an Ageing, Science \& Technology Lens 32, 319-334.

Bramer WM, Rethlefsen ML, Kleijnen J and Franco OH (2017) Optimal database combinations for literature searches in systematic reviews: a prospective exploratory study. Systematic Reviews 6, 245.

Butcher E and Breheny M (2016) Dependence on place: a source of autonomy in later life for older Maori. Journal of Aging Studies 37, 48-58.

Centers for Disease Control and Prevention (CDC) (2019) Healthy Places Terminology. Available at https://www.cdc.gov/healthyplaces/terminology.htm.

Chen C-K, Shie A-J, Wang K-M and Yu C-H (2015) An ageing-in-place service innovation model by using TRIZ methodology. Human Factors and Ergonomics in Manufacturing \& Service Industries 25, $166-182$.

Costa-Font J, Elvira D and Mascarilla-Miró O (2009) 'Ageing in place'? Exploring elderly people's housing preferences in Spain. Urban Studies 46, 295-316.

Cramm JM, Van Dijk HM and Nieboer AP (2018) The creation of age-friendly environments is especially important to frail older people. Ageing \& Society 38, 700-720.

Doblas JL (2018) Living Arrangements among the Elderly. Revista Española de Investigaciones Sociológicas 161, 23-40.

Dobner S, Musterd S and Droogleever Fortuijn J (2016) 'Ageing in place': experiences of older adults in Amsterdam and Portland. GeoJournal: Spatially Integrated Social Sciences and Humanities 81, 197-209.

European Commission (2015) The 2015 Ageing Report. Brussels: European Commission.

EUROSTAT (2011) Active ageing and solidarity between generations: A statistical portrait of the European Union 2012. Publications Office of the European Union.

Fernández-Carro C (2016) Ageing at home, co-residence or institutionalisation? Preferred care and residential arrangements of older adults in Spain. Ageing \& Society 36, 586-612.

Giacalone D, Wendin K, Kremer S, Frøst MB, Bredie WL, Olsson V, Otto MH, Skjoldborg S, Lindberg U and Risvik E (2016) Health and quality of life in an aging population-Food and beyond. Food quality and preference $47,166-170$.

Grimmer K, Kay D, Foot J and Pastakia K (2015) Consumer views about aging-in-place. Clinical Interventions in Aging 10, 1803.

Han JH and Kim J-H (2017) Variations in ageing in home and ageing in neighbourhood. Australian Geographer 48, 255-272.

Hillcoat-Nallétamby S and Ogg J (2014) Moving beyond 'ageing in place': older people's dislikes about their home and neighbourhood environments as a motive for wishing to move. Ageing \& Society 34, 1771-1796.

Horner B and Boldy DP (2008) The benefit and burden of 'ageing-in-place' in an aged care community. Australian Health Review: A Publication of the Australian Hospital Association 32, 356-365.

Iecovich E (2014) Aging in place: from theory to practice. Anthropological Notebooks 20, 21-33.

International Federation of Ageing (IFA) (2011) Global Ageing. Toronto: IFA.

Joanna Briggs Institute (2015) Joanna Briggs Institute Reviewers: Manual 2015: Methodology for JBI Scoping Reviews. Adelaide, Australia: University of Adelaide.

John DH and Gunter K (2016) engAGE in community. Journal of Applied Gerontology 35, 1095.

Kerbler B, Sendi R and Filipovic Hrast M (2017) The relationship of the elderly toward their home and living environment. Urbani Izziv 28, 96-109.

Laslett P (1987) The Emergence of the Third Age. Ageing \& Society 7, 133-160.

Lesthaeghe R (2010) The Unfolding Story of the Second Demographic Transition. In Institute of social research. University of Michigan, Michigan, p. 46.

Levac D, Colquhoun $\mathbf{H}$ and O'Brien K (2010) Scoping studies: advancing the methodology. Implementation Science 5, 1-9.

Machielse A (2016) Afgezonderd of ingesloten? Over sociale kwetsbaarheid van ouderen. Inaugural speech. Rotterdam, The Netherlands: Universiteit voor Humanistiek.

Magnusson L, Hanson E and Borg M (2004) A literature review study of Information and Communication Technology as a support for frail older people living at home and their family carers. Technology of Disability 16, 223-235.

Martens CT (2017) Aging in Which Place? Connecting Aging in Place with Individual Responsibility, Housing Markets, and the Welfare State. Journal of Housing For the Elderly 32, 1-11. 
Means R (2007) Safe as houses? Ageing in place and vulnerable older people in the UK. Social Policy \& Administration 41, 65-85.

Mesthrige JW and Cheung SL (2019) Critical evaluation of 'ageing in place' in redeveloped public rental housing estates in Hong Kong. Ageing \& Society, 1-34. Available online doi:10.1017/ S0144686X19000448.

Milligan C (2009) There's No Place Like Home. Place and Care in an Ageing Society. Farnham, UK: Ashgate.

Norazizan SARS, Rosnah MY, Aizan HT, Una GSC and Rizal HM (2006) Ageing-in-place: towards an ergonomically designed home environment for older Malaysians. Gerontechnology 5, 92-98.

Peace S, Holland C and Kellaher L (2011) 'Option recognition' in later life: variations in ageing in place. Ageing \& Society 31, 734-757.

Peek STM, Luijkx KG, Vrijhoef HJM, Nieboer ME, Aarts S, van der Voort CS, Rijnaard MD and Wouters EJM (2017) Origins and consequences of technology acquirement by independent-living seniors: towards an integrative model. BMC Geriatrics 17, 1.

Peek STM, Wouters EJM, van Hoof J, Luijkx KG, Boeije HR and Vrijhoef HJM (2014) Review: Factors influencing acceptance of technology for aging in place: a systematic review. International Journal of Medical Informatics 83, 235-248.

Renaut S, Ogg J, Petite S and Chamahian A (2015) Home environments and adaptations in the context of ageing. Ageing \& Society 35, 1278-1303.

Roberts E, Bishop A, Ruppert-Stroescu M, Clare G, Hermann J, Singh C, Balasubramanan M, Struckmeyer KM, Mihyun K and Slevitch L (2017) Active Aging for L.I.F.E.: an intergenerational public health initiative addressing perceptions and behaviors around longevity, independence, fitness, and engagement. Topics in Geriatric Rehabilitation 33, 211.

Roy N, Dubé R, Després C, Freitas A and Légaré F (2018) Choosing between staying at home or moving: A systematic review of factors influencing housing decisions among frail older adults. PLoS ONE 13, $1-32$.

Sixsmith A and Sixsmith J (2008) Ageing in place in the United Kingdom. Ageing International 32, 219-235. Van Dijk HM, Cramm JM, Van Exel JOB and Nieboer AP (2015) The ideal neighbourhood for ageing in place as perceived by frail and non-frail community-dwelling older people. Ageing \& Society 35, 1771.

Van Hees S, Horstman K, Jansen M and Ruwaard D (2017) Photovoicing the neighbourhood: understanding the situated meaning of intangible places for ageing-in-place. Health and Place 48, 11-19.

Van Hees S, Horstman K, Jansen M and Ruwaard D (2018) Meanings of 'lifecycle robust neighbourhoods': constructing versus attaching to places. Ageing \& Society 38, 1148-1173.

Van Hoof J, Kort HS, Rutten PG and Duijnstee MS (2011) Ageing-in-place with the use of ambient intelligence technology: perspectives of older users. International Journal of Medical Informatics 80, 310-331.

Van Nimwegen $\mathbf{N}$ and Ekamper $\mathbf{P}$ (2018) Vergrijzing. Demos: bulletin over bevolking en samenleving 34, $5-7$.

Vasunilashorn S, Steinman BA, Liebig PS and Pynoos J (2012) Aging in Place: Evolution of a Research Topic Whose Time Has Come. Journal of Aging Research 1-6.

Vermij L (2016) Kleine gebaren. The Hague, The Netherlands: Sociaal Cultureel Plan Bureau.

Versey HS (2018) A tale of two Harlems: gentrification, social capital, and implications for aging in place. Social Science \& Medicine 214, 1-11.

Wiles JL, Leibing A, Guberman N, Reeve J and Allen RE (2011) The Meaning of "Ageing in Place" to Older People. The Gerontologist 52, 357-366.

Wilkinson-Meyers L, Brown P, McLean C and Kerse N (2014) Met and unmet need for personal assistance among community dwelling New Zealanders 75 years and over. Health \& Social Care in the Community 22, 317-327.

World Health Organization (2015) World Report on Ageing and Health. Geneva: World Health Organization.

Cite this article: Pani-Harreman KE, Bours GJJW, Zander I, Kempen GIJM, van Duren JMA (2021). Definitions, key themes and aspects of 'ageing in place': a scoping review. Ageing \& Society 41, 2026-2059. https://doi.org/10.1017/S0144686X20000094 